\title{
Crystal Structure, Thermal Behaviour and Vibrational Spectra of Tetraethylammonium Dihydrogenmonophosphate Bis Phosphoric Acid
}

\author{
Ikram Dhouib $^{1^{*}}$, Salih Al-Juaid ${ }^{2}$, Tahar Mhiri ${ }^{1}$, Zakaria Elaoud $^{1}$ \\ ${ }^{1}$ Laboratoire de l'Etat Solide, Département de Chimie, Faculté des Sciences de Sfax, Sfax, Tunisia \\ ${ }^{2}$ Chemistry Department, Faculty of Science, King Abdulaziz University, Jeddah, KSA \\ Email: "ikramdhouib82@yahoo.fr
}

Received January 18, 2013; revised February 25, 2013; accepted March 3, 2013

\begin{abstract}
Single crystals of the tetraethylammonium dihydrogenmonophosphate bis trihydrogenmonophosphate $\left[\mathrm{CH}_{3} \mathrm{CH}_{2}\right]_{4} \mathrm{~N}^{+}\left(\mathrm{H}_{2} \mathrm{PO}_{4}^{-}\right)\left(\mathrm{H}_{3} \mathrm{PO}_{4}\right)_{2}(\mathrm{TEP})$, were grown by slow evaporation solution technique at room temperature. The compound was characterised by IR, Raman, differential thermal analysis (TG-DTA) and single crystal X-ray diffraction. It crystallizes in the monoclinic system (space group $P 2_{1} / c$ ) with the following unit cell dimensions: $a=$ 7.765 (2) $\AA, b=16.531$ (4) $\AA, c=14.843$ (2) $\AA, \beta=100.99(2)^{\circ}, Z=4, D_{x}=1.67 \mathrm{Mg} \cdot \mathrm{m}^{-3}, \quad D m=1.532 \mathrm{Mg} \cdot \mathrm{m}^{-3}, \lambda$ $(M o K a)=0.71073 \AA, \mu=0.384 \mathrm{~mm}^{-1}, \quad F(000)=991, \mathrm{~T}=20(2)^{\circ}$. The structure was solved by the direct method and refined to final $R$ value of 0.0342 and $R_{w}=0.107$ for 3239 independent reflections. The structure consists of infinite parallel two-dimensional planes built of mutually $\mathrm{H}_{2} \mathrm{PO}_{4}^{-}, \mathrm{H}_{3} \mathrm{PO}_{4}$ tetrahedra and $\left[\left(\mathrm{CH}_{3} \mathrm{CH}_{2}\right)_{4} \mathrm{~N}\right]^{+}$cations connected by strong $\mathrm{O}-\mathrm{H} \cdots \mathrm{O}$ and $\mathrm{C}-\mathrm{H} \cdots \mathrm{O}$ hydrogen bonding. There are no contacts other than van der Waals interactions between the layers.
\end{abstract}

Keywords: Organic Phosphate; Crystalline Structure; Vibrational Spectra; Thermal Behaviour; Differential Thermal Analysis.

\section{Introduction}

In organic-cation monophosphates, the phosphate anions generally observed are the acidic ones $\left[\mathrm{HPO}_{4}\right]^{2-}$ or $\left[\mathrm{H}_{2} \mathrm{PO}_{4}\right]^{-}$. Such anions are interconnected by strong hydrogen bonds so as to build infinite networks with various geometries: ribbons [1], chains [2,3], two-dimensional network [4-6], and three-dimensional network [7]. These entities can be associated to organic molecules to produce compounds having a particular interest as nonlinear optical materials.

During a systematic investigation of interactions between monophosphoric acid and organic molecules containing one or more nitrogen atom different structures of monophosphate salts have been described:

$$
\begin{aligned}
& \mathrm{NH}_{3}\left(\mathrm{CH}_{2}\right)_{2} \mathrm{NH}_{3}\left(\mathrm{H}_{2} \mathrm{PO}_{4}\right)_{2} \quad[8], \\
& \mathrm{NH}_{3}\left(\mathrm{CH}_{2}\right)_{2} \mathrm{NH}_{3}\left(\mathrm{H}_{2} \mathrm{PO}_{4}\right)_{2} \mathrm{H}_{3} \mathrm{PO}_{4} \quad[9], \\
& \mathrm{NH}_{3}\left(\mathrm{CH}_{2}\right)_{2} \mathrm{NH}_{3} \mathrm{HPO}_{4} \quad \text { [2], }
\end{aligned}
$$

\footnotetext{
*Corresponding author.
}

$$
\begin{aligned}
& \mathrm{NH}_{3}\left(\mathrm{CH}_{2}\right)_{3} \mathrm{NH}_{3} \mathrm{HPO}_{4} \cdot \mathrm{H}_{2} \mathrm{O} \text { [10], } \\
& \mathrm{NH}_{3}\left(\mathrm{CH}_{2}\right)_{3} \mathrm{NH}_{3}\left(\mathrm{H}_{2} \mathrm{PO}_{4}\right)_{2} \text { [11], } \\
& \mathrm{NH}_{3}\left(\mathrm{CH}_{2}\right)_{4} \mathrm{NH}_{3} \mathrm{HPO}_{4} \cdot 2 \mathrm{H}_{2} \mathrm{O} \text { [12], } \\
& \mathrm{NH}_{3}\left(\mathrm{CH}_{2}\right)_{4} \mathrm{NH}_{3}\left(\mathrm{H}_{2} \mathrm{PO}_{4}\right)_{2} \text { [13], } \\
& {\left[\mathrm{NH}_{3}\left(\mathrm{CH}_{2}\right)_{2} \mathrm{NH}_{2}\left(\mathrm{CH}_{2}\right)_{2} \mathrm{NH}_{2}\left(\mathrm{CH}_{2}\right)_{2} \mathrm{NH}_{3}\right] \text { [14], }} \\
& \left(\mathrm{HPO}_{4}\right)_{2} \cdot 2 \mathrm{H}_{2} \mathrm{O} \\
& {\left[\mathrm{C}_{6} \mathrm{H}_{5} \mathrm{CH}_{2} \mathrm{CHCH}_{2} \mathrm{CH}_{2} \mathrm{NH}_{2} \mathrm{CH}_{2} \mathrm{CH}_{2}\right] \cdot \mathrm{H}_{2} \mathrm{PO}_{4} \text { [15], }} \\
& {\left[\mathrm{C}_{6} \mathrm{H}_{5} \mathrm{CH}_{2} \mathrm{NH}_{2} \mathrm{CH}_{3}\right] \cdot \mathrm{H}_{2} \mathrm{PO}_{4} \cdot \mathrm{H}_{2} \mathrm{O} \text { [16], }} \\
& {\left[\mathrm{NH}_{3}\left(\mathrm{CH}_{2}\right)_{2}\right]_{2} \mathrm{NH} \cdot \mathrm{HPO}_{4} \cdot 2 \mathrm{H}_{2} \mathrm{O} \quad[17,18] \text {. }}
\end{aligned}
$$

In the present work we describe the chemical preparation, the crystal structure, calorimetric measurements and Fourier transform infrared (FTIR) spectral characterization of a new compound: the tetraethylammonium dihydrogenmonophosphate bis trihydrogenmonophosphate $\left[\mathrm{CH}_{3} \mathrm{CH}_{2}\right]_{4} \mathrm{~N}+\left(\mathrm{H}_{2} \mathrm{PO}_{4}^{-}\right)\left(\mathrm{H}_{3} \mathrm{PO}_{4}\right)^{2}$, here after abbreviated to (TEP), which is a close analogue of previously ob- 
tained $\left[\mathrm{CH}_{3} \mathrm{CH}_{2}\right]_{4} \mathrm{~N}^{+}\left(\mathrm{H}_{2} \mathrm{AsO}_{4}^{-}\right)\left(\mathrm{H}_{3} \mathrm{AsO}_{4}\right)_{2}$ [19].

\section{Experimental}

\subsection{Synthesis}

The crystal of TEP is easily prepared by slow evaporation at room temperature of an aqueous solution of $\mathrm{H}_{3} \mathrm{PO}_{4}$ and $\left[\left(\mathrm{CH}_{3} \mathrm{CH}_{2}\right)_{4} \mathrm{NOH}\right]$. Schematically the reaction is:

$$
\begin{aligned}
& {\left[\left(\mathrm{CH}_{3} \mathrm{CH}_{2}\right)_{4} \mathrm{NOH}\right]+3 \mathrm{H}_{3} \mathrm{PO}_{4} \rightarrow} \\
& {\left[\mathrm{CH}_{3} \mathrm{CH}_{2}\right]_{4} \mathrm{~N}^{+}\left(\mathrm{H}_{2} \mathrm{PO}_{4}^{-}\right)\left(\mathrm{H}_{3} \mathrm{PO}_{4}\right)_{2}+\mathrm{H}_{2} \mathrm{O}}
\end{aligned}
$$

After some days of evaporation, colorless needle-shaped monocrystals appear in the solution. The chemical analysis of phosphorus and acidic proton has been carried out [20].

Density was measured at room temperature by flotation in toluene. The average value of density,

$$
D m=1.532 \mathrm{Mg} \cdot \mathrm{m}^{-3},
$$

is agreement with that calculated,

$$
D x=1.598 \mathrm{Mg} \cdot \mathrm{m}^{-3} \text {. }
$$

The cell contains two formula units of

$$
\left[\mathrm{CH}_{3} \mathrm{CH}_{2}\right]_{4} \mathrm{~N}\left(\mathrm{H}_{2} \mathrm{PO}_{4}\right)\left(\mathrm{H}_{3} \mathrm{PO}_{4}\right)_{2} \text {. }
$$

\subsection{Characterizations}

The infrared spectrum was recorded in the range 400$4000 \mathrm{~cm}^{-1}$ with a "Perkin Elmer FTIR-1000" spectrophotometer using a sample dispersed in a $\mathrm{KBr}$ pellet. Back scattering Raman spectra were obtained under microscope with a Horiba Jobin Yvon Raman spectrometer (Lab RAM HR $800 \lambda=633 \mathrm{~nm}$ ) in the $50-4050 \mathrm{~cm}^{-1}$ range.

Setaram thermoanalyser, TG-DTA92, was used to perform thermal treatment on samples of

$$
\left[\mathrm{CH}_{3} \mathrm{CH}_{2}\right]_{4} \mathrm{~N}\left(\mathrm{H}_{2} \mathrm{PO}_{4}\right)\left(\mathrm{H}_{3} \mathrm{PO}_{4}\right)_{2} \text {. }
$$

TG-DTA thermograms were obtained with $34.35 \mathrm{mg}$ sample in an open platinum crucible, heated in air with $5^{\circ} \mathrm{C} \cdot \mathrm{min}^{-1}$ heating rate, from room temperature to $275^{\circ} \mathrm{C}$, an empty crucible was used as reference.

\subsection{X-Ray Single Crystal Structure Determination}

Single-crystal X-ray data

$$
\left[\mathrm{CH}_{3} \mathrm{CH}_{2}\right]_{4} \mathrm{~N}\left(\mathrm{H}_{2} \mathrm{PO}_{4}\right)\left(\mathrm{H}_{3} \mathrm{PO}_{4}\right)_{2}
$$

were collected at room temperature on a Nonius KappaCCD diffractometer using Mo- $\mathrm{K}_{\alpha}$ radiation $\lambda=0.71073$ $\AA$ through the program COLLECT [21]. Correction for

\begin{tabular}{|c|c|}
\hline 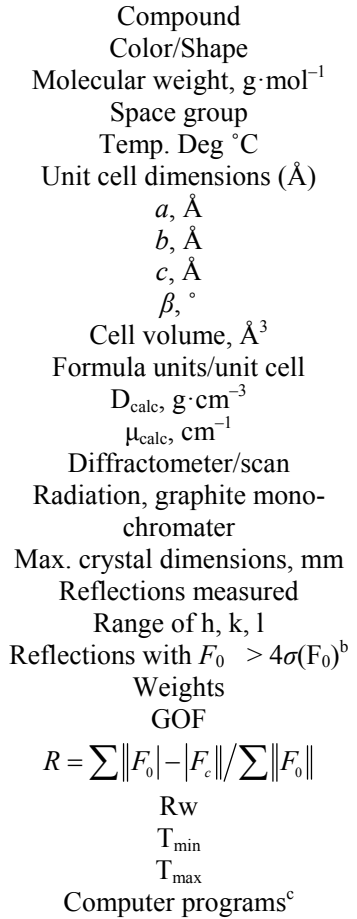 & 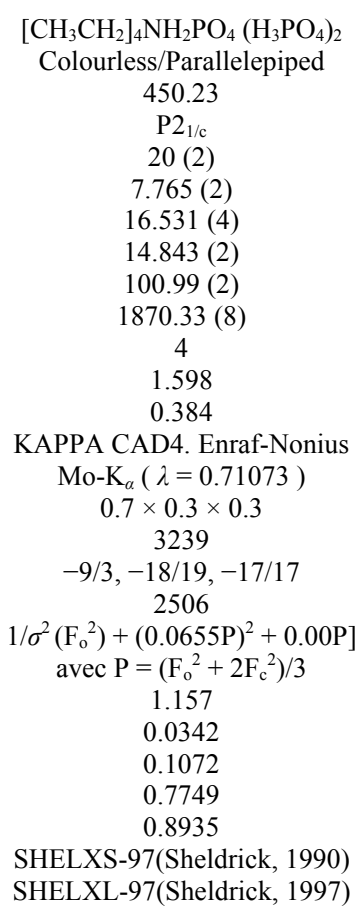 \\
\hline
\end{tabular}
Lorentz-polarisation effect, peak integration and background determination were carried out with the program DENZO [22]. Frame scaling and unit cell parameters refinement were performed with the program
Table 1. Crystal data and summary of intensity data collection and structure refinement.

\section{SCALE-PACK [22].}

Pertinent details of the crystal structure of $\left[\mathrm{CH}_{3} \mathrm{CH}_{2}\right]_{4} \mathrm{~N}\left(\mathrm{H}_{2} \mathrm{PO}_{4}\right)\left(\mathrm{H}_{3} \mathrm{PO}_{4}\right)$ are listed in Table 1. The crystal structure has been solved and refined in the monoclinic symmetry, space group $P 2_{1} / c$, using the WINGX environment [23] and based on SHELXS97 [24] and SHELXL97 [25] softwares. All the hydrogen positions of the diprotonated cation were placed geometrically and held in the riding mode, the $\mathrm{C}-\mathrm{H}$ bonds were fixed and affined at 0.78 and $1.01 \AA$, respectively). Interatomic distances, bond angles and the hydrogen bonds scheme are listed in Tables $\mathbf{2}$ and $\mathbf{3}$ respectively.

\section{Results and Discussion}

\subsection{Structural Analysis}

The asymmetric unit is composed of one $\left[\mathrm{H}_{2} \mathrm{PO}_{4}\right]^{-}$ anion, two neutral phosphoric acid $\left[\mathrm{H}_{3} \mathrm{PO}_{4}\right]$ and one $\left[\left(\mathrm{CH}_{3} \mathrm{CH}_{2}\right)_{4} \mathrm{~N}\right]^{+}$cation. The structural arrangement of $\left[\mathrm{CH}_{3} \mathrm{CH}_{2}\right]_{4} \mathrm{~N}\left(\mathrm{H}_{2} \mathrm{PO}_{4}\right)\left(\mathrm{H}_{3} \mathrm{PO}_{4}\right)_{2}$ can be described as an alternation of organic $\left[\mathrm{N}\left(\mathrm{C}_{2} \mathrm{H}_{5}\right)_{4}\right]^{+}$groups and inorganic $\left(\mathrm{H}_{2} \mathrm{PO}_{4}\right)\left(\mathrm{H}_{3} \mathrm{PO}_{4}\right)_{2}$ is illustrated in Figure 1, viewed in projection along the direction of its two-fold screw axes.

One can distinguish the chains of the acid molecules and the chains of the dihydrogenphosphates anions running parallel to the $Z$ axis in each layer (see Figure 2).

The molecules/anions in the chains are related to each 
Table 2. Principal intratomic distances $(\AA)$ and bond angles $\left({ }^{\circ}\right)$ in $\left[\mathrm{CH}_{3} \mathrm{CH}_{2}\right]_{4} \mathrm{~N}^{+}\left(\mathrm{H}_{2} \mathrm{PO}_{4}^{-}\right)\left(\mathrm{H}_{3} \mathrm{PO}_{4}\right)_{2}$.

\begin{tabular}{|c|c|c|c|}
\hline \multicolumn{2}{|c|}{ Tetrahedron around $P$} & \multicolumn{2}{|c|}{$\left[\mathrm{CH}_{3} \mathrm{CH}_{2}\right]_{4} \mathrm{~N}^{+}$cations } \\
\hline P1-O1 & $1.552(2)$ & $\mathrm{N}-\mathrm{C} 1$ & $1.512(3)$ \\
\hline $\mathrm{P} 1-\mathrm{O} 2$ & $1.496(2)$ & $\mathrm{N}-\mathrm{C} 2$ & $1.522(3)$ \\
\hline P1-O3 & $1.554(2)$ & $\mathrm{N}-\mathrm{C} 3$ & $1.526(3)$ \\
\hline P1-O4 & $1.544(2)$ & \multirow{4}{*}{$\mathrm{N}-\mathrm{C} 4$} & \multirow{4}{*}{$1.522(3)$} \\
\hline O1-H1 & $0.78(5)$ & & \\
\hline O4-H4 & $0.84(4)$ & & \\
\hline $\mathrm{O} 3-\mathrm{H} 3$ & $0.78(4)$ & & \\
\hline O2-P1-O4 & $110.0(1)$ & C1-C6 & $1.517(4)$ \\
\hline O2-P1-O1 & $111.54(1)$ & $\mathrm{C} 2-\mathrm{C} 8$ & $1.509(4)$ \\
\hline O4-P1-O1 & $108.1(1)$ & $\mathrm{C} 3-\mathrm{C} 5$ & $1.516(3)$ \\
\hline O4-P1-O3 & $108.1(1)$ & $\mathrm{C} 4-\mathrm{C} 7$ & $1.517(3)$ \\
\hline O1-P1-O3 & $104.5(1)$ & $\mathrm{C} 1-\mathrm{N}-\mathrm{C} 4$ & $110.4(2)$ \\
\hline $\mathrm{O} 2-\mathrm{P} 1-\mathrm{O} 3$ & $113.5(1)$ & $\mathrm{C} 1-\mathrm{N}-\mathrm{C} 2$ & $107.0(2)$ \\
\hline P2-O5 & $1.511(2)$ & $\mathrm{C} 4-\mathrm{N}-\mathrm{C} 2$ & $110.9(2)$ \\
\hline P2-O6 & $1.505(2)$ & $\mathrm{C} 1-\mathrm{N}-\mathrm{C} 3$ & $111.1(2)$ \\
\hline P2-O7 & $1.56(12)$ & $\mathrm{C} 4-\mathrm{N}-\mathrm{C} 3$ & $106.5(2)$ \\
\hline P2-O8 & $1.571(2)$ & & \\
\hline O6-H6 & $0.82(1)$ & $\mathrm{C} 2-\mathrm{N}-\mathrm{C} 3$ & $111.0(2)$ \\
\hline O7-H7 & $0.82(4)$ & & \\
\hline O6-P2-O5 & $114.63(9)$ & $\mathrm{C} 8-\mathrm{C} 2-\mathrm{N}$ & $114.9(2)$ \\
\hline O6-P2-O7 & $106.19(9)$ & $\mathrm{C} 7-\mathrm{C} 4-\mathrm{N}$ & $114.8(2)$ \\
\hline $\mathrm{O} 5-\mathrm{P} 2-\mathrm{O} 7$ & $110.64(1)$ & $\mathrm{C} 5-\mathrm{C} 3-\mathrm{N}$ & $114.4(2)$ \\
\hline O6-P2-O8 & $107.63(9)$ & C1-C6-N & $115.1(2)$ \\
\hline $\mathrm{O} 5-\mathrm{P} 2-\mathrm{O} 8$ & $109.45(1)$ & & \\
\hline O7-P2-O8 & $108.05(1)$ & & \\
\hline P3-O9 & $1.547(12)$ & & \\
\hline P3-O10 & $1.540(2)$ & & \\
\hline P3-O11 & $1.505(2)$ & & \\
\hline P3-O12 & $1.554(2)$ & & \\
\hline O9-H9 & $0.86(4)$ & & \\
\hline O10-H10 & $0.78(4)$ & & \\
\hline O12-H12 & $0.83(4)$ & & \\
\hline O11-P3-O10 & $113.71(9)$ & & \\
\hline O11-P3-O9 & $108.93(9)$ & & \\
\hline O10-P3-O9 & $105.66(9)$ & & \\
\hline O11-P3-O12 & $111.7(1)$ & & \\
\hline O10-P3-O12 & $106.7(1)$ & & \\
\hline O9-P3-O12 & $109.97(9)$ & & \\
\hline
\end{tabular}

Table 3. Principal interatomic distances $(\AA)$ and bond angles $\left({ }^{\circ}\right)$ and detailed of the hydrogen bonding scheme.

\begin{tabular}{ccccc}
\hline $\mathrm{D}-\mathrm{H} \cdots \mathrm{A}$ & $\begin{array}{c}\mathrm{d}(\mathrm{D}-\mathrm{H}) \\
(\AA)\end{array}$ & $\begin{array}{c}\mathrm{d}(\mathrm{H} \cdots \mathrm{A}) \\
(\AA)\end{array}$ & $\begin{array}{c}\mathrm{d}(\mathrm{D} \cdots \mathrm{A}) \\
(\AA)\end{array}$ & $\begin{array}{c}\mathrm{D}-\mathrm{H} \cdots \mathrm{A} \\
\left(\text { angle }^{\circ}\right)\end{array}$ \\
\hline $\mathrm{O} 1-\mathrm{H} 1 \cdots \mathrm{O} 2^{\mathrm{v}}$ & $0.78(5)$ & $1.81(5)$ & $2.578(2)$ & $170(5)$ \\
$\mathrm{O} 3-\mathrm{H} 3 \cdots \mathrm{O} 11$ & $0.78(4)$ & $1.83(4)$ & $2.598(2)$ & $174(5)$ \\
$\mathrm{O} 4-\mathrm{H} 4 \cdots \mathrm{O} 6$ & $0.84(4)$ & $1.72(4)$ & $2.554(2)$ & $171(4)$ \\
$\mathrm{O} 9-\mathrm{H} 9 \cdots \mathrm{O} 5^{\mathrm{i}}$ & $0.86(4)$ & $1.68(4)$ & $2.521(2)$ & $165(4)$ \\
$\mathrm{O} 7-\mathrm{H} 7 \cdots \mathrm{O} 2^{\mathrm{ii}}$ & $0.82(4)$ & $1.83(4)$ & $2.617(2)$ & $162(4)$ \\
$\mathrm{O} 10-\mathrm{H} 10 \cdots \mathrm{O} 6$ & $0.78(4)$ & $1.76(4)$ & $2.539(2)$ & $177(4)$ \\
$\mathrm{O} 12-\mathrm{H} 12 \cdots \mathrm{O} 5^{\text {iii }}$ & $0.83(4)$ & $1.75(4)$ & $2.584(2)$ & $178(4)$ \\
$\mathrm{C} 1-\mathrm{H} 1 \mathrm{~B} \cdots 8^{\text {iv }}$ & $1.01(3)$ & $2.37(3)$ & $3.315(3)$ & $154(2)$ \\
\hline
\end{tabular}

Symmetry codes: ${ }^{\mathrm{i}}-\mathrm{x}+1,-\mathrm{y}+1,-\mathrm{z}+1 ;{ }^{\mathrm{ii}}-\mathrm{x}+1,-\mathrm{y}+2,-\mathrm{z}+1 ;{ }^{\mathrm{iii}}-\mathrm{x}+2$, $-\mathrm{y}+1,-\mathrm{z}+1 ;{ }^{\mathrm{iv}} \mathrm{x}, \mathrm{y}-1, \mathrm{z} ;{ }^{\mathrm{v}}-\mathrm{x}+2,-\mathrm{y}+2,-\mathrm{z}+1 ;{ }^{\mathrm{vi}} \mathrm{x}+1, \mathrm{y}, \mathrm{z}$.
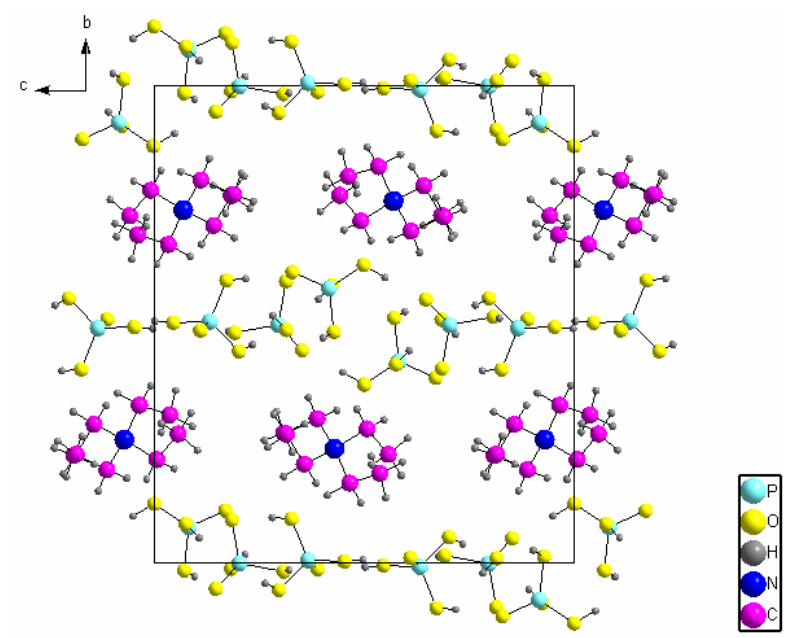

Figure 1. Projection along the a axis of the atomic arrangement of $\left[\mathrm{CH}_{3} \mathrm{CH}_{2}\right]_{4} \mathrm{~N}^{+}\left(\mathrm{H}_{2} \mathrm{PO}_{4}^{-}\right)\left(\mathrm{H}_{3} \mathrm{PO}_{4}\right)_{2}$.

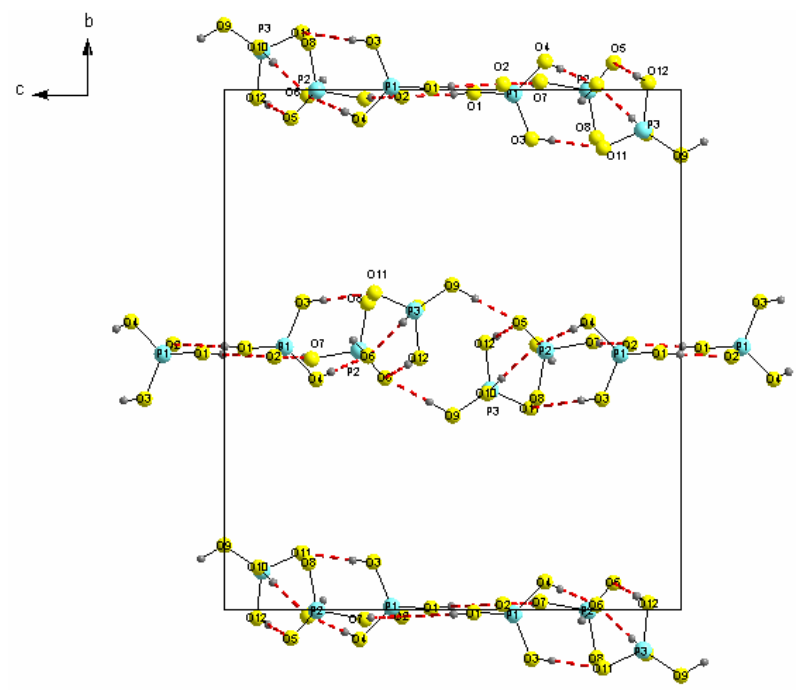

Figure 2. Projection along the axis of the inorganic arrangement.

other by the two-fold screw axis. The distance (P (1) - P (3) $=4.313$ (1) $\AA$ ) between two $\mathrm{H}_{3} \mathrm{PO}_{4}$ groups linked by 
hydrogen bond is shortened when compared to the remaining P-P bond lengths P (1) - P (2): 4.499 (1) $\AA$ and $\mathrm{P}(2)-\mathrm{P}(3)$ : 4.369 (1) $\AA$ between $\mathrm{H}_{3} \mathrm{PO}_{4}$ and $\mathrm{H}_{2} \mathrm{PO}_{4}^{-}$ groups. The $\mathrm{H}_{2} \mathrm{P}(2) \mathrm{O}_{4}^{-}$anions, $\mathrm{H}_{3} \mathrm{P}(1) \mathrm{O}_{4}$ and $\mathrm{H}_{3} \mathrm{P}(3) \mathrm{O}_{4}$ molecules are joined into trimmers by the hydrogen bonds (see Table 3). The dihydrogenphosphate anions $\mathrm{H}_{2} \mathrm{P}(2) \mathrm{O}_{4}^{-}$and the acid $\mathrm{H}_{3} \mathrm{P}(3) \mathrm{O}_{4}$ molecules do not form any straight contact between themselves. All their of $\mathrm{H}_{2} \mathrm{P}(2) \mathrm{O}_{4}^{-}$one $\mathrm{O}-\mathrm{H}$ groups are involved in the hydrogen bonds with the $\mathrm{O}(7)$ atoms of the acid $\mathrm{H}_{3} \mathrm{P}(1) \mathrm{O}_{4}$ molecules and all their of $\mathrm{H}_{3} \mathrm{P}(3) \mathrm{O}_{4}$ three $\mathrm{O}-\mathrm{H}$ group are involved in the hydrogen bonds with the $\mathrm{O}(9), \mathrm{O}(10)$ and $\mathrm{O}(12)$ of the dihydrogenphosphate anions $\mathrm{H}_{2} \mathrm{P}(2) \mathrm{O}_{4}^{-}$.

The acid $\mathrm{H}_{3} \mathrm{P}(1) \mathrm{O}_{4}$ molecules form strong $\left(\mathrm{O} 1-\mathrm{H} 1 \cdots \mathrm{O} 2^{v}\right)$ hydrogen bonds between themselves.

Note that the $\mathrm{O}(5)$ atoms of the dihydrogenphosphates anions participate in two hydrogen bonds with the $\mathrm{OH}$ groups $(\mathrm{O}(9)-\mathrm{H}(9)$ and $(\mathrm{O}(12)-\mathrm{H}(12))$ of the neighbour orthophosphoric acid molecules of the same chain.

The structure is based on sheets of $\mathrm{H}_{2} \mathrm{PO}_{4}^{-}$and $\mathrm{H}_{3} \mathrm{PO}_{4}$ tetrahedra fused together by strong intralayer $\mathrm{O}-\mathrm{H} \cdots \mathrm{O}$ hydrogen bonds, giving to trimmers, $\mathrm{d}(\mathrm{O})-\mathrm{O}$ $<2.73 \AA$ ) $[26,27]$. The midplanes of these clusters, are located at $z=0.25$ and $z=0.75$.

The organic group of tetraethylammonium monocation structure is similar to that in the TESe and TEAs analogue $[19,28]$. Each tetrapropylammonium cation makes three short contacts with trimmers of the dihydrogenarsenate through the $\mathrm{C}-\mathrm{H} \cdots \mathrm{O}$ hydrogen bonds: $\mathrm{C} 1-\mathrm{H} 1 \mathrm{~B} \cdots \mathrm{O}^{i v}$ (see Table 3). The $\mathrm{H} \cdots \mathrm{O}$ distance is equal to 2.37 (3) $\AA$, respectively. The $\mathrm{C} \cdots \mathrm{O}$ distance is equal to 3.315 (3) $\AA$, showing that those hydrogen bonds are very weak [29]. The $\mathrm{C}-\mathrm{H} \cdots \mathrm{O}$ angle is equal to 154(2). The structure of the tetrapropylammonium cation is similar to that in the crystals of tetraethylammonium chloride, is in the tetraethylammonium chloride monohydrate [30], tetraethylammonium chloride tetrahydrate [31] and anhydrous tetraethyl- ammonium chloride [32]. The lengths of the $\mathrm{N}-\mathrm{C}$ bonds are in the range between $1.512(3)(\mathrm{N}-\mathrm{Cl})$ and $1.516(3) \AA(\mathrm{N}-\mathrm{C} 3)$. The lengths of the other two N-C bonds are equal to 1.522 (3) $\AA$. The $\mathrm{C}-\mathrm{N}-\mathrm{C}$ angles are in between 106.5(2) to 111.1(2) ${ }^{\circ}$. The $\mathrm{C}-\mathrm{C}$ bonds lengths are in the region between 1.509(4) and $1.517(4)$. Thus, they are very similar. The final coordinates and $U_{e q}$ or $U_{i s o}$ of TEP are given in Table 4.

\subsection{Vibrational Investigations}

The FT-IR and FT-Raman spectra of the title crystal were measured for the powder sample at room temperature. The bands observed in the measured region arise from the vibrations of hydrogen bonds, vibrations of the tetrapropylammonium cation, phosphate groups, and lattice vibrations. Vibrational spectra are shown in Fig- ures 3 and 4 .

\subsubsection{The Hydrogen Bond Vibrations}

The valence vibrations of O-H groups interconnected by a system of hydrogen bonds in the crystal appear in IR spectrum as broad bands in the $3500-1800 \mathrm{~cm}^{-1}$ region [15]. As can be seen from Table 3, these consist of hydrogen bonds of $\mathrm{O}-\mathrm{H} \cdots \mathrm{O}$ type with length ranging from 2.521(2) to 2.617 (2) $\AA$. X-ray data show that $\mathrm{H}$ atoms of $\mathrm{OH}$ groups generate hydrogen bonds with the oxygen atoms of the $\mathrm{PO}_{4}$ group.

The stretching type of vibrations of hydrogen bonds $v \mathrm{OH}$ displays a well defined and medium intense band in IR with the $A B$ structure in the region between 3500 and $2000 \mathrm{~cm}^{-1}$. In IR spectrum the frequency of A band is $2750 \mathrm{~cm}^{-1}$ and B is $2460 \mathrm{~cm}^{-1}$. For Raman experiment the broad maxima are found at 2822 and $2550 \mathrm{~cm}^{-1}$. The intense IR bands correspond to a strong hydrogen bond with the $\mathrm{O} \cdots \mathrm{O}$ distance in the region $2.6 \AA-2.7 \AA$ [33]. The in-plane $\mathrm{OH}$ bending mode $\delta \mathrm{OH}$ gives rise to a medium band in infrared spectrum without counterparts in Raman spectrum at $1252 \mathrm{~cm}^{-1}$. The out-of-plane bending

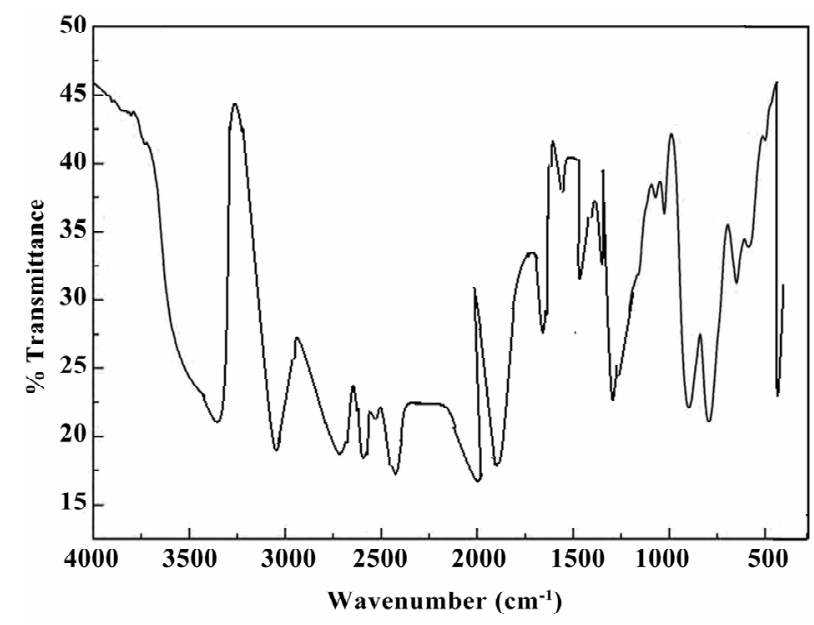

Figure 3. IR spectrum of $\left[\mathrm{CH}_{3} \mathrm{CH}_{2}\right]_{4} \mathrm{~N}\left(\mathrm{H}_{2} \mathrm{PO}_{4}\right)\left(\mathrm{H}_{3} \mathrm{PO}_{4}\right)_{2}$.

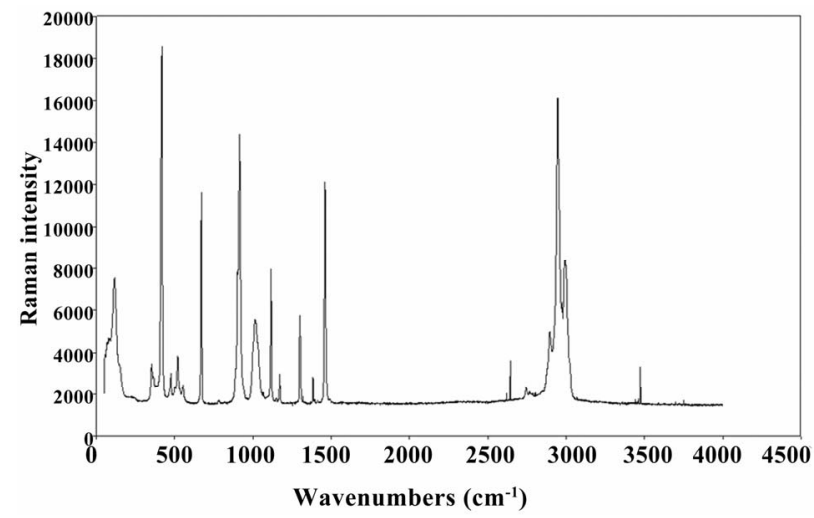

Figure 4. Raman spectrum of $\left[\mathrm{CH}_{3} \mathrm{CH}_{2}\right]_{4} \mathrm{~N}\left(\mathrm{H}_{2} \mathrm{PO}_{4}\right)\left(\mathrm{H}_{3} \mathrm{PO}_{4}\right)_{2}$. 
Table 4. Principal intratomic distances ( $\AA)$ and bond angles ( $\left(^{\circ}\right)$ in $\left[\mathrm{CH}_{3} \mathrm{CH}_{2}\right]_{4} \mathbf{N}^{+}\left(\mathrm{H}_{2} \mathrm{PO}_{4}^{-}\right)\left(\mathrm{H}_{3} \mathrm{PO}_{4}\right)_{2} U_{\mathrm{eq}}=\frac{1}{3} \sum_{i} \sum_{j} U_{i j} a_{i} * a_{j} * a_{i} a_{j}$.

\begin{tabular}{|c|c|c|c|c|}
\hline Atoms & $\mathrm{x} / \mathrm{a}$ & $\mathrm{y} / \mathrm{b}$ & $\mathrm{z} / \mathrm{c}$ & Ueq or Uiso ${ }^{*}$ \\
\hline P1 & $0.15869(7)$ & $0.49303(4)$ & 0.13317 (4) & $0.0127(2)$ \\
\hline P2 & $0.70980(7)$ & $0.49978(4)$ & 0.2963 (4) & $0.0113(2)$ \\
\hline P3 & $0.20672(7)$ & $0.42355(4)$ & $0.4170(4)$ & $0.0114(2)$ \\
\hline $\mathrm{O}(1)$ & $0.2430(2)$ & $0.4957(1)$ & $0.0464(1)$ & $0.0196(4)$ \\
\hline $\mathrm{O}(2)$ & $-0.0332(2)$ & $0.5117(1)$ & $0.1105(1)$ & $0.0198(4)$ \\
\hline $\mathrm{O}(3)$ & $0.1999(2)$ & $0.4066(1)$ & $0.1727(1)$ & $0.0181(4)$ \\
\hline $\mathrm{O}(4)$ & $0.2539(2)$ & $0.5555(1)$ & $0.2025(1)$ & $0.0174(4)$ \\
\hline $\mathrm{O}(5)$ & $0.8479(2)$ & $0.5531(1)$ & $0.3526(1)$ & $0.0139(4)$ \\
\hline $\mathrm{O}(6)$ & $0.5279(2)$ & $0.5109(1)$ & $0.3156(1)$ & $0.0149(4)$ \\
\hline $\mathrm{O}(7)$ & $0.6960(2)$ & $0.5166(1)$ & 0.1917 (1) & $0.0238(5)$ \\
\hline $\mathrm{O}(8)$ & $0.7616(2)$ & $0.4086(1)$ & $0.3146(1)$ & $0.0194(4)$ \\
\hline $\mathrm{O}(9)$ & $0.1654(2)$ & $0.3748(1)$ & $0.4992(1)$ & $0.0150(4)$ \\
\hline $\mathrm{O}(10)$ & $0.4068(2)$ & $0.4171(1)$ & $0.4239(1)$ & $0.0185(4)$ \\
\hline $\mathrm{O}(11)$ & $0.1023(2)$ & 0.38909 (1) & $0.3296(1)$ & $0.0153(4)$ \\
\hline $\mathrm{O}(12)$ & $0.1651(2)$ & $0.51456(1)$ & $0.4281(1)$ & $0.0165(4)$ \\
\hline $\mathrm{H} 1$ & $0.171(6)$ & $0.492(3)$ & $0.002(3)$ & $0.065(15)^{*}$ \\
\hline $\mathrm{H} 3$ & $0.165(6)$ & $0.404(3)$ & $0.218(3)$ & $0.073(14)^{*}$ \\
\hline $\mathrm{H} 4$ & $0.350(5)$ & $0.541(2)$ & $0.235(3)$ & $0.051(11)^{*}$ \\
\hline H6 & $0.4600(2)$ & $0.4802(3)$ & $0.2829(2)$ & $0.022(11)^{*}$ \\
\hline $\mathrm{H} 7$ & $0.793(5)$ & $0.514(2)$ & $0.178(3)$ & $0.048(11)^{*}$ \\
\hline H9 & $0.180(5)$ & $0.401(3)$ & $0.550(3)$ & $0.064(13)^{*}$ \\
\hline $\mathrm{H} 10$ & $0.446(5)$ & $0.446(2)$ & $0.392(2)$ & $0.045(11)^{*}$ \\
\hline H12 & $0.063(5)$ & $0.527(2)$ & $0.403(3)$ & $0.042(10)^{*}$ \\
\hline $\mathrm{n}$ & $0.6747(2)$ & $0.2404(1)$ & $0.5702(1)$ & $0.0159(4)$ \\
\hline $\mathrm{C}(1)$ & $0.8236(3)$ & $0.2084(2)$ & $0.6421(2)$ & $0.0200(5)$ \\
\hline C (2) & $0.5598(3)$ & $0.1684(2)$ & $0.5342(2)$ & $0.0217(5)$ \\
\hline C (3) & $0.7439(3)$ & $0.2823(2)$ & $0.4926(2)$ & $0.0180(5)$ \\
\hline C (4) & $0.5705(3)$ & $0.3036(2)$ & $0.6116(2)$ & $0.0172(5)$ \\
\hline $\mathrm{C}(5)$ & $0.8522(4)$ & $0.2285(2)$ & $0.4423(2)$ & $0.0251(6)$ \\
\hline $\mathrm{C}(6)$ & $0.9576(3)$ & $0.2711(2)$ & $0.6843(2)$ & $0.0259(6)$ \\
\hline$C(7)$ & $0.4887(4)$ & $0.2736(2)$ & $0.6904(2)$ & $0.0250(6)$ \\
\hline C (8) & $0.4006(4)$ & $0.1887(2)$ & $0.4623(2)$ & $0.0314(7)$ \\
\hline $\mathrm{H}(1 \mathrm{~A})$ & $0.879(4)$ & $0.169(2)$ & $0.6136(19)$ & $0.024(7)^{*}$ \\
\hline $\mathrm{H}(1 \mathrm{~B})$ & $0.768(3)$ & $0.182(2)$ & $0.6914(18)$ & $0.022(7)^{*}$ \\
\hline $\mathrm{H}(2 \mathrm{~A})$ & $0.627(4)$ & $0.127(2)$ & $0.5076(19)$ & $0.023(7)^{*}$ \\
\hline $\mathrm{H}(2 \mathrm{~B})$ & $0.527(3)$ & $0.143(2)$ & $0.5870(18)$ & $0.018(7)^{*}$ \\
\hline $\mathrm{H}(3 \mathrm{~A})$ & $0.811(4)$ & $0.324(2)$ & $0.517(2)$ & $0.028(8)^{*}$ \\
\hline $\mathrm{H}(3 \mathrm{~B})$ & $0.641(3)$ & $0.301(2)$ & $0.4522(18)$ & $0.015(6)^{*}$ \\
\hline $\mathrm{H}(4 \mathrm{~A})$ & $0.653(3)$ & 0.348 2) & $0.632(2)$ & $0.017(7)^{*}$ \\
\hline $\mathrm{H}(4 \mathrm{~B})$ & $0.483(3)$ & $0.321(2)$ & $0.564(2)$ & $0.012(6)^{*}$ \\
\hline $\mathrm{H}(5 \mathrm{~A})$ & $0.948(4)$ & $0.207(2)$ & $0.482(2)$ & $0.023(7)^{*}$ \\
\hline $\mathrm{H}(5 \mathrm{~B})$ & 0.787 (4) & $0.185(2)$ & $0.411(2)$ & $0.029(8)^{*}$ \\
\hline $\mathrm{H}(5 \mathrm{c})$ & 0.897 (4) & $0.263(2)$ & $0.396(2)$ & $0.025(7)^{*}$ \\
\hline $\mathrm{H}(6 \mathrm{~A})$ & $1.020(4)$ & $0.292(2)$ & $0.641(2)$ & $0.029(8)^{*}$ \\
\hline $\mathrm{H}(6 \mathrm{~B})$ & $0.903(4)$ & $0.312(2)$ & $0.715(2)$ & $0.041(9)^{*}$ \\
\hline $\mathrm{H}(6 \mathrm{C})$ & $1.040(4)$ & $0.244(2)$ & $0.729(2)$ & $0.035(8)^{*}$ \\
\hline
\end{tabular}


Continued

\begin{tabular}{|c|c|c|c|c|}
\hline $\mathrm{H}(7 \mathrm{~A})$ & $0.576(4)$ & $0.258(2)$ & $0.737(2)$ & $0.031(8)^{*}$ \\
\hline $\mathrm{H}(7 \mathrm{~B})$ & $0.406(4)$ & $0.233(2)$ & $0.671(2)$ & $0.027(8)^{*}$ \\
\hline $\mathrm{H}(7 \mathrm{C})$ & $0.420(4)$ & $0.318(2)$ & $0.708(2)$ & $0.030(8)^{*}$ \\
\hline $\mathrm{H}(8 \mathrm{~A})$ & $0.429(4)$ & $0.212(2)$ & $0.409(2)$ & $0.036(9)^{*}$ \\
\hline $\mathrm{H}(8 \mathrm{~B})$ & $0.348(5)$ & $0.137(3)$ & 0.448 & $0.062(1)^{*}$ \\
\hline $\mathrm{H}(8 \mathrm{C})$ & $0.311(5)$ & 0.225 & $0.483(3)$ & $0.064(1)^{*}$ \\
\hline
\end{tabular}

${ }^{*}$ is relatif to Uiso of hydogen.

$\gamma \mathrm{OH}$ mode appears in the region 900 and $700 \mathrm{~cm}^{-1}$, but is not observed in spectra measured at ambient temperature.

\subsubsection{The Tetraethylammonium Cation Vibrations}

The frequencies observed in the infrared spectra at 2977 and $2957 \mathrm{~cm}^{-1}$ are assigned to the $\delta$ symmetric $\mathrm{CH}_{2}$ and Sasymmetric $\mathrm{CH}_{3}$ absorptions; the different modes of asymmetric ( $\delta \mathrm{as})$ and symmetric $(\delta \mathrm{s})$ deformation of the methyl groups are found at 1495 and $1397 \mathrm{~cm}^{-1}$, respectively. A weak band which appeared at $1323 \mathrm{~cm}^{-1}$ is related to the N-C vibration $[34,35]$. Besides, sharp bands at 1196,1172 and $1102,1116 \mathrm{~cm}^{-1}$ are associated to $\mathrm{CH}_{3}$ and $\mathrm{CH}_{2}$ rocking vibration modes in IR and spectively. The two bands observed at $952 \mathrm{~cm}^{-1}$ in IR and $915 \mathrm{~cm}^{-1}$ in Raman were assigned to $v_{1}\left(\mathrm{NC}_{4}\right)$ stretchRaman, reing modes [36-38]. The deformation mode $v_{2}\left(\mathrm{NC}_{4}\right)$ appears at 744 and $672 \mathrm{~cm}^{-1}$ in IR and Raman spectrum, respectively. The splitting $v(\mathrm{C}-\mathrm{C}-\mathrm{C}-\mathrm{N})$ bending mode at $772 \mathrm{~cm}^{-1}$ may correspond to different conformers of the organic chains. The band observed at $463 \mathrm{~cm}^{-1}$ in infrared and $478 \mathrm{~cm}^{-1}$ in Raman spectrum arises from the deformation vibration $v_{4}\left(\mathrm{NC}_{4}\right)$ of the TEP entity.

\subsubsection{Internal Vibrations of the Phosphate Groups}

The unperturbed $\mathrm{PO}_{4}^{3-}$ ion is a tetrahedron with a point group symmetry $T_{d}$. The $v_{1}(A)$ and $v_{3}(F 2)$ symmetric and asymmetric stretching modes are observed in $1000-700$ $\mathrm{cm}^{-1}$ region, whereas the $\mathrm{v}_{2}(E)$ and $\mathrm{v}_{4}(F 2)$ symmetric and asymmetric bending modes are distinguished in the $500-400 \mathrm{~cm}^{-1}$ domain $[39,40]$.

The interpreting of the IR and Raman spectrum is made in terms of internal modes of two atomic groups, $\mathrm{PO}_{2}$ and $\mathrm{P}(\mathrm{OH})_{2}$, included in $\mathrm{H}_{2} \mathrm{PO}_{4}^{-}$anion. The two stretching vibrations, asymmetric and symmetric of $\mathrm{PO}_{2}$ group, are observed in the region $1065-895 \mathrm{~cm}^{-1}$; while those related to $\mathrm{P}(\mathrm{OH})$, group occur as two intense bands in the domain $1000-861 \mathrm{~cm}^{-1}$. The splitting of F2 stretching mode of $\mathrm{PO}_{4}$, into three intense components at $1059,1032,889 \mathrm{~cm}^{-1}$ is a strong evidence of the symmetry lowering of $\mathrm{H}_{2} \mathrm{PO}_{4}$ in the solid state. On the other hand, bending modes of $\mathrm{H}_{2} \mathrm{PO}_{4}$ group are observed at lower frequencies. The bands located in the region 487 $400 \mathrm{~cm}^{-1}$, are respectively attributed to the torsion $\rho\left(\mathrm{PO}_{2}\right)$, to the wagging $\omega\left(\mathrm{PO}_{2}\right)$, and to the bending $\delta\left[\mathrm{P}(\mathrm{OH})_{2}\right]$ vibrations.

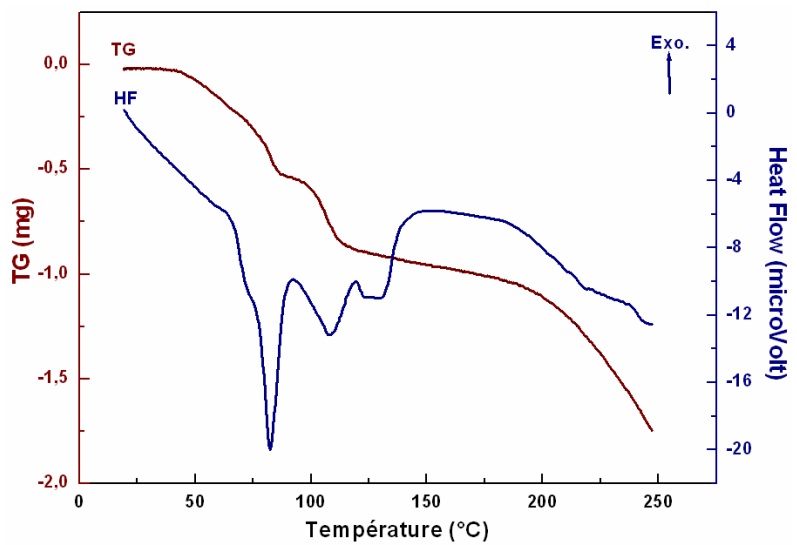

Figure 5. The TG-DSC curve of $\left[\mathrm{CH}_{3} \mathrm{CH}_{2}\right]_{4} \mathrm{~N}\left(\mathrm{H}_{2} \mathrm{PO}_{4}\right)$ $\left(\mathrm{H}_{3} \mathrm{PO}_{4}\right)_{2}$.

\subsection{Thermal Analysis (DSC and ATG)}

DSC-ATG of TEP was done in air at the rate of $5^{\circ} \mathrm{C} / \mathrm{min}$. One more characteristic feature of the room temperature TEP is its high hygroscopicity (Figure 5), which illustrates the calorimetric (DSC) and thermogravimetric (TGA) results. This compound is stable until $320 \mathrm{~K}$, above this temperature, or loss of weight appears at 355 $\mathrm{K}$ and $381 \mathrm{~K}$. It is due to the departure of adsorbed water. The endothermic peak observed at $T=401 \mathrm{~K}$ is attributed to the melting of TEP.

\section{Conclusions}

Crystals of a hybrid material,

$$
\left(\mathrm{CH}_{3} \mathrm{CH}_{2}\right)_{4} \mathrm{~N}\left(\mathrm{H}_{2} \mathrm{PO}_{4}\right)\left(\mathrm{H}_{3} \mathrm{PO}_{4}\right)_{2} \text {, }
$$

have been prepared by slow evaporation of aqueous solution $\left(\mathrm{CH}_{3} \mathrm{CH}_{2}\right)_{4} \mathrm{NOH}$ and $\mathrm{H}_{3} \mathrm{PO}_{4}$ at room temperature.

The structure consists of strong two dimensional character based on sheets of $\mathrm{H}_{2} \mathrm{PO}_{4}^{-}$and $\mathrm{H}_{3} \mathrm{PO}_{4}$ tetrahedra fused together by strong intralayer $\mathrm{O}-\mathrm{H} \cdots \mathrm{O}$ hydrogen bonds, giving to trimmers. The planes of inorganic groups alternate with planes of organic cations. In addition, the two layers spreading in this network are themselves interconnected by strong $\mathrm{O}-\mathrm{H} \cdots \mathrm{O}$ and $\mathrm{C}-\mathrm{H} \cdots \mathrm{O}$ hydrogen bonding.

Vibrational study recorded is of great interest as it 
verifies the dependence of groups constituting our material. The hydrogen bonds confirmed by IR and X-Ray diffraction explain the stability of our compound.

\section{REFERENCES}

[1] L. Baouab and A. Jouini, "Crystal Structures and Thermal Behavior of Two New Organic Monophosphates," Journal of Solid State Chemistry, Vol. 141, No. 2, 1998, pp. 343-351. doi:10.1006/jssc. 1998.7933

[2] M. T. Averbuch-Pouchot and A. Durif, "Structures of Ethylenediammonium Monohydrogentetraoxophosphate(V) and Ethylenediammonium Monohydrogentetraoxoarsenate(V)," Acta Crystallographica, Vol. C43,1987, pp. 18941896. doi:10.1107/S0108270187089716

[3] M. T. Averbuch-Pouchot, A. Durif and J. C. Guitel, "Structures of -Alanine, DL-Alanine and Sarcosine Monophosphates," Acta Crystallographica, Vol. C44, 1988, pp. 1968-1972. doi:10.1107/S0108270188000502

[4] M. T. Averbuch-Pouchot, A. Durif and J. C. Guitel, "Structures of Glycine Monophosphate and Glycine Cyclo-Triphosphate," Acta Crystallographica, Vol. C44, 1988, pp. 99-102. doi:10.1107/S0108270187008539

[5] M. Bagieu-Beucher, "Structure of Cytosinium Dihydrogenmonophosphate," Acta Crystallographica, Vol. C46, 1990, p. 238.

[6] R. H. Blessing, "Hydrogen Bonding and Thermal Vibrations in Crystalline Phosphate Salts of Histidine and Imidazole," Acta Crystallographica, Vol. B42, 1986, pp. 613-621. doi:10.1107/S0108768186097641

[7] M. T. Averbuch-Pouchot, A. Durif and J. C. Guitel, "Structure of Ethylenediammonium Dihydrogentetraoxophosphate(V) Pentahydrogenbis[Tetraoxophosphate(V)]," Acta Crystallographica, Vol. C45, 1989, pp. 421-423. doi:10.1107/S0108270188011977

[8] S. Kamoun, M. Kamoun, A. Jouini and A. Daoud, "Structure of Ethylenediammonium Bis(Dihydrogenmonophosphate)," Acta Crystallographica, Vol. C45, 1989, pp. 481482. doi:10.1107/S0108270188012405

[9] M. Bagieu-Beucher, A. Durif and J. C. Guitel, "Structure of Ethylenediammonium Dihydrogentetraoxophosphate(V) Pentahydrogenbis[tetraoxophosphate(V)]," Acta Crystallographica, Vol. C43, 1989, pp. 421-423. doi:10.1107/S0108270188011977

[10] S. Kamoun, A. Jouini and A. Daoud, "Structure du Propanediammonium-1,3 Monohydrogénomonophosphate Monohydrate," Acta Crystallographica, Vol. C47, 1991, pp. 117-119. doi:10.1107/S0108270190003122

[11] S. Kamoun, A. Jouini, A. Daoud, A. Durif and J. C. Guitel, "Structure du Diammonium-1,3 Propane Bis(Dihydrogénomonophosphate)," Acta Crystallographica, Vol. C48, 1992, pp. 133-135.

doi:10.1107/S0108270191008077

[12] S. Kamoun and A. Jouini, "Etude Calorimétrique et Structure Cristalline du Putrescinium Monohydrogénomonophosphate Dihydrate $\mathrm{NH}_{3}\left(\mathrm{CH}_{2}\right)_{4} \mathrm{NH}_{3} \mathrm{HPO}_{4} 2 \mathrm{H}_{2} \mathrm{O}$," Journal of Solid State Chemistry, Vol. 89, No. 1, 1990, pp. 67-74. doi:10.1016/0022-4596(90)90294-8
[13] F. Takusagaxa and T. F. Koetzle, "A Study of the Charge Density in Putrescine Diphosphate at 85 K," Acta Crystallographica, Vol. B35, 1979, pp. 867-877. doi:10.1107/S0567740879005082

[14] Z. Elaoud, S. Kamoun, T. Mhiri and J. J. Jaud, "Crystal Structure of Triethylentetraammonium Bis Monohydrogenmonophosphate Dihydrate,

$\left[\mathrm{NH}_{3}\left(\mathrm{CH}_{2}\right)_{2} \mathrm{NH}_{2}\left(\mathrm{CH}_{2}\right)_{2} \mathrm{NH}_{2}\left(\mathrm{CH}_{2}\right)_{2} \mathrm{NH}_{3}\right]\left(\mathrm{HPO}_{4}\right)_{2} \cdot 2 \mathrm{H}_{2} \mathrm{O}$," Journal of Chemical Crystallography, Vol. 29, 1999, pp. 541-545.

[15] Z. Elaoud, S. Kamoun, T. Mhiri, F. Romain and H. J. Burzlaff, "Crystal Structure and Phase Transitions in N-benzyl Piperidinium Dihydrogenmonophosphate,

$\mathrm{C}_{6} \mathrm{H}_{5} \mathrm{CH}_{2} \mathrm{CHCH}_{2} \mathrm{CH}_{2} \mathrm{NH}_{2} \mathrm{CH}_{2} \mathrm{CH}_{2} \cdot \mathrm{H}_{2} \mathrm{PO}_{4}$," Journal of Solid State Chemistry, Vol. 155, 2000, pp. 298-304.

[16] Z. Elaoud, S. Kamoun, J. J. Jaud and T. Mhiri, "Crystal Structure of N-benzylmethylammonium Dihydrogen-Monophosphate Monohydrate,

$\left[\mathrm{C}_{6} \mathrm{H}_{5} \mathrm{CH}_{2} \mathrm{NH}_{2} \mathrm{CH}_{3}\right] \mathrm{H}_{2} \mathrm{PO}_{4} \cdot \mathrm{H}_{2} \mathrm{O}$," Journal of Chemical Crystallography, Vol. 28, 1998, pp. 313-315. doi:10.1023/A:1021861621824

[17] S. Kamoun, A. Jouini and A. Daoud, "Structure du Aza-3 Pentanediyle-1,5 Diammonium Monohydrogénomonophosphate Dihydrate," Acta Crystallographica, Vol. C46, 1990, pp. 1481-1483. doi:10.1107/S0108270189012552

[18] S. Kamoun, A. Daoud, A. Elfakir, M. Quarton and I. Ledoux, "Linear and Nonlinear-Optical Properties on N-Diethylendiammonium Monohydrogenophosphate Dihydrate," Journal of Solid State Chemistry, Vol. 94, 1995, pp. 893896.

[19] C. Lee and W. T. A. Harrison, "Tetraethylammonium Dihydrogenarsenate Bis(Arsenic Acid) and 1,4-Diazoniabicyclo[2.2.2] octane Bis(Dihydrogenarsenate) Arsenic Acid: Hydrogen-Bonded Networks Containing Dihydrogenarsenate Anions and Neutral Arsenic Acid Molecules," Acta Crystallographica, Vol. C63, 2007, pp. m308-m311. doi:10.1107/S0108270107023967

[20] G. Charlot, “Chimie Analytique Quantitative," Vol. 2, Masson and Cie, Paris, 1974.

[21] E. A. Muller, R. J. Cannon, A. N. Sarjeant, K. M. Ok, P. S. Halasyamani and A. J. Norquist, "Directed Synthesis of Noncentrosymmetric Molybdates," Crystal Growth \& Design, Vol. 5, No. 5, 2005, pp. 1913-1917. doi: $10.1021 / \operatorname{cg} 050184 \mathrm{z}$

[22] Nonius, "Kappa CCD Program Software," Nonius BV, Delft, 1998.

[23] L. J. Farrugia, "WinGX Suite for Small-Molecule SingleCrystal Crystallography," Journal of Applied Crystallography, Vol. 32, 1999, p. 837. doi:10.1107/S0021889899006020

[24] G. M. Sheldrick, "SHELXS-97 Programs for Crystal Solution," University of Göttingen, Göttingen, 1997.

[25] G. M. Sheldrick, "SHELXL-97 Programs for Crystal Structure Refinement," University of Göttingen, Göttingen, 1997.

[26] I. D. Brown, "On the Geometry of O-H...O Hydrogen Bonds," Acta Crystallographica, Vol. A32, 1976, pp. 2431. doi:10.1107/S0567739476000041 
[27] R. H. Blessing. "Hydrogen Bonding and Thermal Vibrations in Crystalline Phosphate Salts of Histidine and Imidazole," Acta Crystallographica, Vol. B42, 1986, pp. 613621. doi:10.1107/S0108768186097641

[28] J. Baran, M. Śledź, M. Drozd, A. Pietraszko, A. Haznar and H. Ratajczak, "Structural, Vibrational and DSC Investigations of the Tetraethylammonium Hydrogenselenate Crystal," Journal of Molecular Structure, Vol. 526, 2000, pp. 361-371. doi:10.1016/S0022-2860(00)00530-5

[29] E. Steinwender, E. T. G. Lutz, J. H .van der Maas and J. A. Kanters, "2-Ethynyladamantan-2-ol: A Model Compound with Distinct $\mathrm{OH} \cdots \pi$ and $\mathrm{CH} \cdots \mathrm{O}$ Hydrogen Bonds," Vibrational Spectroscopy, Vol. 4, No. 2, 1993, pp. 217-229. doi:10.1016/0924-2031(93)87041-Q

[30] J. H. Loehlin and A. Kvick, "Tetraethylammonium Chloride Monohydrate," Acta Crystallographica, Vol. B34, 1978, pp. 3488-3490. doi:10.1107/S0567740878011425

[31] T. C. W. Mak, H. J. B. Slot and P. T. Beurskens, "Tetraethylammonium Chloride Tetrahydrate, a 'Double Channel' Host Lattice Constructed from $\left(\mathrm{H}_{2} \mathrm{O}\right)_{4} \mathrm{Cl}^{-}$Tetrahedra Linked between Vertices," Journal of Inclusion Phenomena, Vol. 4, No. 3, 1986, p. 295. doi:10.1007/BF00658004

[32] R. J. Staples and Z. Kristallogr, "Crystal Structure of 4,4-Dimethyloxazolidine-2-Thione, $\mathrm{C}_{5} \mathrm{H}_{9} \mathrm{NOS}$," NCS, 1999 , pp. 214- 231.

[33] A. Novak, "Hydrogen Bonding in Solids Correlation of Spectroscopic and Crystallographic Data," Structure and Bonding, Vol. 18, 1974, pp. 177-178. doi:10.1007/BFb0116438

[34] M. Gosniowska, Z. Ciunik, G. Bator, R. Jakubas and J. Baran, "Structure and Phase Transitions in Tetramethylammonium Tetrabromoindate(III) and Tetraethylammonium Tetrabromoindate(III) Crystals," Journal of Molecular Structure, Vol. 555, 2000, p. 243.

\section{Supplementary Material}

CCDC831725 contains the supplementary crystallographic data for 1 . These data can be obtained free of charge via www.ccdc.cam.ac.uk/data_request/cif or by emailing

\section{doi:10.1016/S0022-2860(00)00607-4}

[35] M. Karbowiak, J. Hanuza, J. Janczak and J. Drozdzynski, "Synthesis, Structural and Spectroscopic Properties of Tetra(Tetraethylammonium) Heptaisothiocyanato Uranate (III) and Neodymate(III)," Journal of Alloys and Compounds, Vol. 225, 1995, p. 338. doi:10.1016/0925-8388(94)07117-9

[36] H. G. Heddrich and C. E. Blom, "Flame Diagnostics and Molecular Constants of $\mathrm{CaO}$ by Tunable Diode Laser Spectroscopy," The Journal of Chemical Physics, Vol. 90, 1989, p. 4660. doi:10.1063/1.456610

[37] H. G. Heddrich and C. E. Blom, "The Infrared Spectrum of Barium Oxide in the Gas Phase," Journal of Molecular Spectroscopy, Vol. 140, 1990, p. 103. doi:10.1016/0022-2852(90)90009-F

[38] A. D. Kirkwood, K. D. Bier, J. K. Thompson, T. L. Haslett, A. S. Hubber and M. Moskovits, "Ultraviolet-Visible and Raman Spectroscopy of Diatomic Manganese Isolated in Rare-Gas Matrixes," The Journal of Chemical Physics, Vol. 95, 1991, p. 2644. doi: $10.1021 / \mathrm{j} 100160 \mathrm{a} 006$

[39] G. Ma, T. Zhang, K. Yu and J. Braz, "Synthesis, X-Ray Crystal Structure and Thermal Decomposition Mechanism of $\left[\mathrm{Zn}(\mathrm{MCZ})_{3}\right]\left(\mathrm{NO}_{3}\right)_{2} \cdot \mathrm{H}_{2} \mathrm{O}(\mathrm{MCZ}=$ Methyl Carbazate)," Journal of the Brazilian Chemical Society, Vol. 16, 2005, p. 796. doi:10.1590/S0103-50532005000500018

[40] M. Drozd, "The Equilibrium Structures, Vibrational Spectra, NLO and Directional Properties of Transition Dipole Moments of Diguanidinium Arsenate Monohydrate and Diguanidinium Phosphate Monohydrate: The Theoretical DFT Calculations," Spectrochimica Acta Part A, Vol. 65, No. 5, 2006, pp. 1069-1086. doi:10.1016/j.saa.2006.02.007

data_request@ccdc.cam.ac.uk, or by contacting the Cambridge Crystallography Data Centre 12, Union Road, Cambridge CB2 1EZ, UK [Fax: +441223336030]. 